19 Revue d'histoire du XIXe siècle

Société d'histoire de la révolution de 1848 et des

révolutions du XIXe siècle

19 | 1999

Aspects de la production culturelle au XIXe siècle

\title{
La Gendarmerie au XIXe siècle
}

\section{OpenEdition}

Journals

Édition électronique

URL : http://journals.openedition.org/rh19/187

DOI : $10.4000 /$ rh 19.187

ISSN : $1777-5329$

Éditeur

La Société de 1848

Édition imprimée

Date de publication : 1 décembre 1999

Pagination : 171-172

ISSN : 1265-1354

Référence électronique

" La Gendarmerie au XIXe siècle », Revue d'histoire du XIXe siècle [En ligne], 19 | 1999, mis en ligne le 26 août 2008, consulté le 15 septembre 2020. URL : http://journals.openedition.org/rh19/187

Ce document a été généré automatiquement le 15 septembre 2020

Tous droits réservés 


\section{La Gendarmerie au XIXe siècle}

Colloque international organisé par le Centre de recherches en histoire du XIXe siècle (Paris I-Paris IV) avec le concours du Service historique de la gendarmerie nationale les 10 et 11 mars 2000 (La Sorbonne, salle Louis Liard). La gendarmerie assume de multiples responsabilités, administratives, judiciaires et militaires. Elle est présente sur tout le territoire. Elle participe à toutes les campagnes. Son histoire se situe au point de rencontre de l'histoire nationale, locale et de l'histoire politique, militaire, sociale et culturelle. Huit séances thématiques rythmeront les deux journées de ce premier colloque universitaire sur l'histoire de la gendarmerie: "L'organisation de la gendarmerie sous la Révolution et l'Empire "; " Les gendarmes, leur statut militaire, leur mémoire "; " Le recueil du renseignement civil et militaire par la gendarmerie "; "Gendarmerie et autres forces de sécurité publique"; "L'implantation de la gendarmerie dans les campagnes et les villes"; "Les gendarmes entre les communautés rurales et l'État ? " ; " La gendarmerie et le sentiment d'insécurité à la fin du siècle "; "La gendarmerie en Europe: exportation du modèle français?". Les travaux se termineront par une table ronde. Outre la nécessité de mieux connaître une histoire très mal étudiée, il importe aussi de se demander pourquoi la société du XIXe siècle, qui se démocratise progressivement, a conservé une police à statut militaire, comment les gendarmes ont-ils contribué à la diffusion de la notion d'État et de l'idée nationale, et quelle a été l'influence à l'étranger, du modèle gendarmique français?

Renseignements: Jean-Noël Luc, Centre de recherches en histoire du XIXe siècle, Colloque Gendarmerie, 17 rue de la Sorbonne, 75231 Paris cedex 05. 